\title{
Povidone-Iodine Demonstrates Rapid In Vitro Virucidal Activity Against SARS-CoV-2, The Virus Causing COVID-19 Disease
}

\author{
Danielle E. Anderson - Velraj Sivalingam • Adrian Eng Zheng Kang • \\ Abhishek Ananthanarayanan · Harsha Arumugam • Timothy M. Jenkins • \\ Yacine Hadjiat · Maren Eggers
}

Received: June 2, 2020 / Published online: July 8, 2020

(C) The Author(s) 2020

\begin{abstract}
Introduction: As of 22 June 2020, Severe Acute Respiratory Syndrome (SARS)-coronavirus (CoV)-2 has infected more than 8.95 million people worldwide, causing $>468,000$ deaths. The virus is transmitted through respiratory droplets and physical contact from contaminated surfaces to the mucosa. Hand hygiene
\end{abstract}

Danielle E. Anderson, Velraj Sivalingam and Adrian Eng Zheng Kang contributed equally to this work.

Electronic supplementary material The online version of this article (https://doi.org/10.1007/s40121020-00316-3) contains supplementary material, which is available to authorized users.

Digital Features To view digital features for this article go to https://doi.org/10.6084/m9.figshare.12555317.

D. E. Anderson $(\bowtie) \cdot$ V. Sivalingam - A. E. Z. Kang Programme in Emerging Infectious Diseases, DukeNUS Medical School, Singapore, Singapore e-mail: danielle.anderson@duke-nus.edu.sg

A. Ananthanarayanan · H. Arumugam - Y. Hadjiat Mundipharma Singapore Holding Pte. Limited, Singapore, Singapore

T. M. Jenkins

Mundipharma Research Limited, Cambridge

Science Park, Cambridge, UK

\section{Eggers ( $\square)$}

Labor Prof. Dr. G. Enders MVZ GbR, Stuttgart, Germany

e-mail: eggers@labor-enders.de and oral decontamination among other measures are key to preventing the spread of the virus. We report the in vitro virucidal activity of topical and oral povidone-iodine (PVP-I) products against SARS-CoV-2.

Methods: Suspension assays were used to assess the virucidal activity of PVP-I against SARSCoV-2. Products were tested at a contact time of $30 \mathrm{~s}$ for virucidal activity. Viral titres were calculated using the Spearman-Kärber method and reported as median tissue culture infectious dose $\left(\mathrm{TCID}_{50}\right) / \mathrm{mL}$.

Results: All four products [antiseptic solution (PVP-I 10\%), skin cleanser (PVP-I 7.5\%), gargle and mouth wash (PVP-I 1\%) and throat spray (PVP-I 0.45\%)] achieved $\geq 99.99 \%$ virucidal activity against SARS-CoV-2, corresponding to $\geq 4 \log _{10}$ reduction of virus titre, within 30 s of contact.

Conclusion: This study provides evidence of rapid and effective virucidal activity of PVP-I against SARS-CoV-2. PVP-I-based products are widely available for medical and personal use for hand hygiene and oral decontamination, and could be readily integrated into coronavirus disease, COVID-19, infection control measures in hospital and community settings.

Keywords: Anti-infective agents; COVID-19; Povidone-iodine; PVP-I; SARS-CoV-2; Upper respiratory tract infections; Viruses 


\section{Key Summary Points}

\section{Why carry out this study?}

To generate evidence of PVP-I virucidal activity against SARS-CoV-2, the virus that causes COVID-19 disease.

With no definitive treatment or vaccine available as yet for COVID-19, effective infection control measures are needed to limit virus spread.

Previous studies showed the efficacy of PVP-I products against similar viruses (SARS-CoV, MERS-CoV) and a range of other viruses, but PVP-I has not yet been directly tested against SARS-CoV-2.

What was learned from the study?

All four tested PVP-I products demonstrated $\geq 4 \log _{10}$ reduction of SARSCoV-2 titres, corresponding to a $\geq 99.99 \%$ kill rate, with a contact time of $30 \mathrm{~s}$. This shows the rapid virucidal activity of the PVP-I products against SARS-CoV-2.

PVP-I-based disinfectants are already widely available and could be readily integrated into existing infection control protocols in both hospital and community settings.

\section{INTRODUCTION}

Coronavirus disease 2019 (COVID-19), caused by Severe Acute Respiratory Syndrome (SARS)coronavirus (CoV)-2 virus, was declared a pandemic by the World Health Organization (WHO) on 11 March 2020 [1]. The number of infections has grown exponentially over a short period of time [2]. As of 22 June 2020, the virus has spread rapidly and infected at least 8.95 million people worldwide, causing over 468,000 deaths from the disease [3].

SARS-CoV-2 is an enveloped, positive-sense, single-stranded RNA virus and belongs to the same class of beta-coronaviruses as SARS-CoV and Middle East Respiratory Syndrome (MERS)$\mathrm{CoV}$, the viruses responsible for the SARS 2003 and MERS 2012 epidemics, respectively [4, 5]. Current evidence indicates that human-to-human transmission primarily occurs through respiratory droplets from coughs or sneezes and/or physical contact [6]. As the virus can persist on contaminated surfaces for days [7], infection can occur indirectly by touch transfer of virus from these surfaces or hands to the mucosa of the mouth, nose or eyes. Thus, infection control measures, such as disinfecting surfaces and good personal and hand hygiene, are important to limit the spread of the virus.

Povidone-iodine (polyvinylpyrrolidone iodine, PVP-I) is a water-soluble complex of povidone, a carrier molecule, and iodine, which has powerful microbicidal activity. PVP-I formulations have been widely used for $>60$ years because of their broad-spectrum antimicrobial activity and established safety profile [8, 9]. PVP-I is on the WHO List of Essential Medicines, which identifies important medicines necessary for a functional healthcare system. PVP-I mouthwash is also included in the WHO R\&D blueprint for experimental therapies against COVID-19, therefore it would be important to demonstrate its direct antiviral activity against the virus [10]. In addition to its broad antibacterial and antifungal activity, PVP-I has demonstrated in vitro activity against a range of viruses [11], including the related SARS-CoV [12] and MERS-CoV [13].

In this study, we evaluated the virucidal activity of four PVP-I products against SARSCoV-2 using a quantitative assay, at a contact time of $30 \mathrm{~s}$.

\section{METHODS}

Four PVP-I products [BETADINE ${ }^{\circledR}$ antiseptic solution (PVP-I 10\% $\mathrm{w} / \mathrm{v}), \quad$ BETADINE $^{\circledR}$ antiseptic skin cleanser (PVP-I 7.5\% w/v), BETADINE $^{\circledR}$ Gargle and mouth wash (PVP-I $1.0 \% \mathrm{w} / \mathrm{v}$ ) and BETADINE ${ }^{\circledR}$ throat spray (PVP-I $0.45 \% \mathrm{w} / \mathrm{v})$ ] were tested at the Animal Biosafety Level (ABSL) 3 facility in the Duke-NUS Medical School, Singapore. BETADINE ${ }^{\circledR}$ Gargle and 
Mouth Wash was tested undiluted and at a 1:2 dilution. The test products were provided by Mundipharma Singapore Holding. Virucidal activity of PVP-I products against SARS-CoV-2 was evaluated in a viral kill time assay, adapting the protocol from the EN14476 disinfectant testing methodology which has previously been used to test the efficacy of Betadine products on SARS-CoV and MERS-CoV. A $\geq 4 \log _{10}(99.99 \%)$ reduction in viral titre represents effective virucidal activity per European standards $[9,12]$. This article does not contain any studies with human participants or animals performed by any of the authors.

\section{Virus Culture}

SARS-CoV-2 (hCoV-19/Singapore/2/2020) was propagated in Vero-E6 cells (American Type Culture Collection). Vero-E6 host cells were maintained in Dulbecco's Modified Eagle Medium containing 5\% fetal bovine serum (DMEM$5 \% \mathrm{FBS}$ ). To prepare the virus stocks, confluent cell monolayers were infected with SARS-CoV-2 and incubated at $37^{\circ} \mathrm{C}, 5 \% \mathrm{CO}_{2}$ for up to 7 days. When cytopathic effects (CPE) were evident microscopically, the supernatant was harvested, clarified by centrifugation and stored at $-80^{\circ} \mathrm{C}$.

\section{PVP-I Cytotoxicity Assay}

PVP-I cytotoxicity was tested by incubating uninfected Vero-E6 cells with tenfold serial dilutions of the PVP-I test products in DMEM$5 \%$ FBS. After incubation at $37^{\circ} \mathrm{C}$ for 4 days, $\mathrm{CPE}$ at each dilution were observed to determine the lowest PVP-I concentration at which cytotoxic effects were absent.

\section{PVP-I Virus Kill-Time Assay}

The exposure of the virus to PVP-I products was performed at $21{ }^{\circ} \mathrm{C}$ for $30 \mathrm{~s}$ to evaluate disinfectant efficacy, as previously described [13]. An amount of $100 \mu \mathrm{L}$ of virus was mixed with 700 $\mu \mathrm{L}$ of PVP-I test product, in the presence of 200 $\mu \mathrm{L}$ phosphate-buffered saline (PBS) containing $0.3 \mathrm{~g} / \mathrm{L} \mathrm{BSA}$ as an interfering substance. Virus controls with $700 \mu \mathrm{L}$ PBS in place of the PVP-I products were included.

After the intended contact time, the reaction of PVP-I was stopped by transfer of $100-\mu \mathrm{L}$ aliquots to $900 \mu \mathrm{L}$ DMEM-5\% FBS. Immediately, tenfold serial dilutions were performed and 100 $\mu \mathrm{L}$ of each dilution was used to inoculate VeroE6 cells (in quadruplicate) in a 96-well microtitre plate. Due to the immediate titration, no after-effect of the test product could occur, as described earlier [9]. The plates were incubated at $37^{\circ} \mathrm{C}$ for 4 days before $\mathrm{CPE}$ assessment. Viral titres were calculated as median tissue culture infectious dose $\left(\mathrm{TCID}_{50} / \mathrm{mL}\right)$ using the Spearman-Kärber method [14, 15].

\section{RESULTS}

The viral kill time assay was performed after first evaluating the cytotoxicity of the products to the Vero-E6 cells. The antiseptic solution, hand sanitiser, throat spray and gargle/mouthwash were non-cytotoxic to the Vero-E6 at dilutions $\geq 1: 100$ and skin cleanser at dilutions $\geq 1: 1000$. This was taken into consideration when the kill time assay was performed.

Initial testing was carried out at $120 \mathrm{~s}$ to evaluate the efficacy of the various PVP-I products against the SARS-CoV-2 and to optimise the assay (Supplementary Table S1). No CPE was observed after SARS-CoV-2 exposure to PVP-I products. Due to the cytotoxicity of the products in Vero-E6 cells, the limit of detection of the assay was $3 \times 10^{3} \quad \mathrm{TCID}_{50} / \mathrm{mL}$. This demonstrated that all the test products were effective against the SARS-CoV-2 virus at $2 \mathrm{~min}$.

To determine the virucidal activity of the product ( $\geq 4 \log _{10}$ reduction in viral titres), the efficacy of the PVP-I products against the SARSCoV-2 virus was tested at an exposure time of $30 \mathrm{~s}$, mandated by the European Chemicals Agency (ECHA) guidelines [16] to demonstrate virucidal efficacy of disinfectants for use in hospitals and at home. All PVP-I products tested at $30 \mathrm{~s}$ demonstrated $\mathrm{a} \geq 4 \log _{10}$ reduction of SARS-CoV-2 titres, corresponding to a $\geq 99.99 \%$ kill for all the tested products, indicating rapid virucidal activity [16], and also 
meeting the ECHA time-points for disinfectant efficacy (Table 1).

\section{DISCUSSION}

There are currently no established effective therapies or vaccines for COVID-19 infection despite many ongoing clinical trials [17]. Hence, treatment for COVID-19 patients relies mostly on supportive care, mechanical ventilation and/or medication previously employed against other coronaviruses [17]. Like SARSCoV, SARS-CoV-2 initially appeared to spread by droplet transmission and direct/indirect contact with symptomatic infected persons. However, asymptomatic and pre-symptomatic persons infected with SARS-CoV-2 can transmit the virus [18]. Moreover, the virus appears more contagious compared to SARS-CoV [19].

Besides physical distancing, preventive measures, such as personal hygiene and frequent disinfection of high-touch surfaces in public spaces and healthcare facilities, are important non-therapeutic interventions to reduce the risk of person-to-person transmission in the community and to protect healthcare workers. The formulations tested have different complementary roles in infection control, including hand and oral hygiene. Firstly, hand hygiene protocols recommended by WHO [6] can be augmented by using disinfectants with proven in vitro virucidal activity against SARSCoV-2, as demonstrated with PVP-I in this study. An earlier hand hygiene simulation study demonstrated superior in vivo efficacy of a PVPI product compared with soft soap or chlorhexidine against the non-pathogenic murine norovirus (MNV) [20]. MNV, a non-enveloped virus, has been used as a model test virus in in vivo simulations for biosafety reasons, and is known to be more resilient to antiseptics than enveloped viruses, such as CoVs [20].

Secondly, given the potential for SARS-CoV2 infection via the oral and nasal mucosa, besides masks, additional respiratory hygiene measures such as throat sprays or gargling can be considered to reduce the risk of SARS-CoV-2 transmission via these routes [9]. COVID-19-related guidelines from several organisations, including the Australian Dental Association and the US Centers for Disease Control and Prevention, have recommended using a preprocedural mouthwash with products such as PVP-I $[21,22]$. A study in Japan showed that, in patients with chronic respiratory diseases, the incidence of episodes of acute exacerbation of chronic respiratory infections decreased significantly after starting regular use of povidoneiodine gargle [23]. Recent studies have shown that SARS-CoV-2 virus shedding is highest during early disease stages and occurs mostly in the upper respiratory tract [24, 25]. Considering these factors, both frequent hand washing and oral hygiene through gargling could help minimise the risk of infections [26].

Table 1 Virucidal activity of PVP-I products against SARS-CoV-2 virus with $30 \mathrm{~s}$ contact time

\begin{tabular}{lc}
\hline PVP-I product & $\begin{array}{l}\text { Reduction in viral titres } \\
\left(\log _{\mathbf{1 0}} \mathbf{T C I D}_{\mathbf{5 0}} / \mathbf{m L}^{\mathbf{m}}\right)\end{array}$ \\
\hline Antiseptic solution (PVP-I 10.0\%) & $\geq 4.00$ \\
Throat spray (PVP-I 0.45\%) & $\geq 4.00$ \\
Skin cleanser (PVP-I 7.5\%) & $\geq 4.00$ \\
Gargle/mouth wash (PVP-I 1.0\%) & $\geq 4.00$ \\
Gargle/mouth wash (PVP-I 1.0\%, 1:2 dilution) & $\geq 4.00$ \\
\hline
\end{tabular}

Data are presented as $\log _{10}$ reductions in viral titres compared to control. The results demonstrate the efficacy and virucidal activity of PVP-I against SARS-CoV-2 in $30 \mathrm{~s}$ of exposure. Viral titre values ranged from $1.5 \times 10^{7}$ to $1 \times 10^{8} \mathrm{TCID}_{50} /$ $\mathrm{mL}$. Results presented are from three independent experiments $(n=3)$ 
A recent study tested the stability of SARSCoV-2 under various environmental conditions, including exposure to PVP-I and other disinfectants for 5, 15 and $30 \mathrm{~min}$ [7]. The results showed that SARS-CoV-2 could remain viable for as long as 6-7 days on some surfaces (stainless steel and plastic), but that it could be inactivated by a number of common disinfectants. The virus was undetectable with exposure times of 5 min or longer when tested with PVP-I $(7.5 \%)$, indicating potential usage in disinfection procedures [7]. Previous studies with PVP-I products on SARS-CoV and MERS-CoV demonstrated rapid virucidal activity in the presence of interfering substances such as erythrocytes to simulate organic soiling ('dirty' conditions). There was no difference observed in the log kill of the viruses in clean versus dirty conditions, indicating that interfering substances do not decrease the antiviral activity of PVP-I $[9,13]$. In these studies, PVP-I was able to rapidly inactivate $\left(\geq 4 \log _{10}\right.$ reduction in $\mathrm{TCID}_{50} / \mathrm{mL}$ in virus titres) the SARS-CoV and MERS-CoV within contact times of $15 \mathrm{~s}$.

\section{CONCLUSION}

The broad-spectrum antimicrobial and rapid virucidal activity of PVP-I products against SARS-CoV-2 suggests its importance in infection control. As an additional protective barrier to the PPE, these products may help reduce disease transmission. PVP-I is easily administered and has been used in both the hospital and community settings for $>60$ years and can thus be readily integrated into existing infection control protocols. PVP-I-based products can be used as part of infection control measures during the COVID-19 pandemic [27-29]. In summary, the use of PVP-I products can augment health and hygiene measures to reduce the spread of COVID-19 in the community.

\section{ACKNOWLEDGEMENTS}

We thank Duke-NUS Medical School ABSL3 facility staff for logistics management and assistance.
Funding. This study, editorial support and the Rapid Service Fees for the publication of this manuscript was funded by Mundipharma Singapore Holding Pte. Limited.

Editorial Assistance. Editorial assistance in the preparation of this article was provided by Sen Kwan Tay of Tech-Observer Asia-Pacific Pte Ltd.

Authorship. All named authors meet the International Committee of Medical Journal Editors (ICMJE) criteria for authorship for this article, take responsibility for the integrity of the work as a whole, and have given their approval for this version to be published.

Authorship Contributions. Danielle E. Anderson, Maren Eggers, Harsha Arumugam, Abhishek Ananthanarayanan, Timothy M. Jenkins, and Yacine Hadjiat designed and supervised research. Danielle E. Anderson, Velraj Sivalingam, and Adrian Eng Zheng Kang conducted experiments. Danielle E. Anderson, Velraj Sivalingam and Adrian Eng Zheng Kang performed analyses. Abhishek Ananthanarayanan, Harsha Arumugam, Yacine Hadjiat, Timothy M. Jenkins, Maren Eggers, and Danielle E. Anderson wrote the paper.

Prior Presentation. A non-peer-reviewed version of this article has been available on a preprint server since 10 Jun 2020 (ResearchSquare: https://www.researchsquare.com/article/rs-34544/v1).

Disclosures. Abhishek Ananthanarayanan, Harsha Arumugam, Timothy M. Jenkins, and Yacine Hadjiat are employees of Mundipharma. Danielle E. Anderson, Velraj Sivalingam, and Adrian Eng Zheng Kang received a Service Contract from Mundipharma for the study. Maren Eggers does Consultancy and Speaker Engagements for Mundipharma.

Compliance with Ethics Guidelines. This article does not contain any studies with human participants or animals performed by any of the authors. 
Data Availability. All data generated or analysed during this study are included in the published article or as supplementary information files.

Open Access. This article is licensed under a Creative Commons Attribution-NonCommercial 4.0 International License, which permits any non-commercial use, sharing, adaptation, distribution and reproduction in any medium or format, as long as you give appropriate credit to the original author(s) and the source, provide a link to the Creative Commons licence, and indicate if changes were made. The images or other third party material in this article are included in the article's Creative Commons licence, unless indicated otherwise in a credit line to the material. If material is not included in the article's Creative Commons licence and your intended use is not permitted by statutory regulation or exceeds the permitted use, you will need to obtain permission directly from the copyright holder. To view a copy of this licence, visit http:// creativecommons.org/licenses/by-nc/4.0/.

\section{REFERENCES}

1. World Health Organisation. WHO Director-General's opening remarks at the media briefing on COVID-19-11 March 2020: World Health Organisation. 2020. https://www.who.int/dg/speeches/ detail/who-director-general-s-opening-remarks-atthe-media-briefing-on-covid-19-11-march-2020. Accessed 11 May 2020.

2. Zhao S, Lin Q, Ran J, et al. Preliminary estimation of the basic reproduction number of novel coronavirus (2019-nCoV) in China, from 2019 to 2020: a data-driven analysis in the early phase of the outbreak. Int J Infect Dis. 2020;92:214-7.

3. Johns Hopkins University and Medicine. Coronavirus Resource Center: John Hopkins University. 2020. https://coronavirus.jhu.edu/map.html. Accessed 22 June 2020 .

4. Corman VM, Muth D, Niemeyer D, Drosten C. Hosts and sources of endemic human coronaviruses. Adv Virus Res. 2018;100:163-88.

5. Zhu N, Zhang D, Wang W, et al. A novel coronavirus from patients with pneumonia in China, 2019. N Engl J Med. 2020;382(8):727-33.
6. World Health Organisation. Interim recommendations on obligatory hand hygiene against transmission of COVID-19: World Health Organization. 2020. https://www.who.int/who-documents-detail/ interim-recommendations-on-obligatory-handhygiene-against-transmission-of-covid-19. Accessed 18 Apr 2020.

7. Chin AWH, Chu JTS, Perera MRA, et al. Stability of SARS-CoV-2 in different environmental conditions. Lancet Microbe. 2020;1:e10.

8. Vogt PM, Hauser J, Mueller S, Bosse B, Hopp M. Efficacy of conventional and liposomal povidoneiodine in infected mesh skin grafts: an exploratory study. Infect Dis Ther. 2017;6(4):545-55.

9. Eggers M, Koburger-Janssen T, Eickmann M, Zorn J. In vitro bactericidal and virucidal efficacy of povidone-iodine gargle/mouthwash against respiratory and oral tract pathogens. Infect Dis Ther. 2018;7(2): 249-59.

10. World Health Organisation. WHO R\&D Blueprint COVID 19 Experimental Treatments: World Health Organisation. 2020. https://www.who.int/docs/ default-source/coronaviruse/covid-classification-oftreatment-types-rev.pdf. Accessed 18 May 2020.

11. Kawana R, Kitamura T, Nakagomi O, et al. Inactivation of human viruses by povidone-iodine in comparison with other antiseptics. Dermatology. 1997;195(Suppl 2):29-35.

12. Kariwa H, Fujii N, Takashima I. Inactivation of SARS coronavirus by means of povidone-iodine, physical conditions and chemical reagents. Dermatology. 2006;212(Suppl 1):119-23.

13. Eggers M, Eickmann M, Zorn J. Rapid and effective virucidal activity of povidone-iodine products against middle east respiratory syndrome coronavirus (MERS-CoV) and modified vaccinia virus Ankara (MVA). Infect Dis Ther. 2015;4(4):491-501.

14. Spearman C. The method of 'right and wrong cases' ('constant stimuli') without Gauss's formulae. Br J Psychol. 1908;2:227-42.

15. Kärber G. Beitrag zur kollektiven Behandlung pharmakologischer Reihenversuche. Archiv Exper Pathol Pharmakol. 1931;162:480-3.

16. Comité Européen de Normalisation. EN14476:2013 + A1:2015: Chemical disinfectants and antiseptics. Quantitative suspension test for the evaluation of virucidal activity in the medical area. Test method and requirements (Phase 2/Step 1) 2015.

17. Cascella M, Rajnik M, Cuomo A, Dulebohn SC, Di Napoli R. Features, evaluation and treatment 
coronavirus (COVID-19). Treasure Island, FL: StatPearls; 2020.

18. Bai Y, Yao L, Wei T, et al. Presumed asymptomatic carrier transmission of COVID-19. JAMA. 2020;323(14):1406-7.

19. Sanche S, Lin YT, Xu C, Romero-Severson E, Hengartner N, Ke R. High contagiousness and rapid spread of severe acute respiratory syndrome coronavirus 2. Emerg Infect Dis. 2020;26(7):1470-7.

20. Eggers M, Koburger-Janssen T, Ward LS, Newby C, Müller S. Bactericidal and virucidal activity of povidone-iodine and chlorhexidine gluconate cleansers in an in vivo hand hygiene clinical simulation study. Infect Dis Ther. 2018;7(2):235-47.

21. Australian Dental Association. Managing COVID19 Guidelines. 2020. https://www.ada.org.au/ Covid-19-Portal/Cards/Dental-Profesionals/

Guidelines-and-Risk-Factors/Just-an-informationCard. Accessed 21 June 2020.

22. Centers for Disease Control and Prevention. Guidance for dental settings: interim infection prevention and control guidance for dental settings during the COVID-19 response: centers for disease control and prevention. 2020. https://www.cdc.gov/ coronavirus/2019-ncov/hcp/dental-settings.html. Accessed 21 June 2020.

23. Nagatake T, Ahmed K, Oishi K. Prevention of respiratory lnfections by povidone-lodine gargle. Dermatology. 2002;204(Suppl 1):32-6.
24. Wölfel R, Corman VM, Guggemos W, et al. Virological assessment of hospitalized patients with COVID-2019. Nature. 2020;581(7809):465-9.

25. To KK, Tsang OT, Leung WS, et al. Temporal profiles of viral load in posterior oropharyngeal saliva samples and serum antibody responses during infection by SARS-CoV-2: an observational cohort study. Lancet Infect Dis. 2020;20(5):565-74.

26. Gui D, Pepe G, Magalini S. Just one more hygiene practice in COVID-19. Eur Rev Med Pharmacol Sci. 2020;24(7):3438-9.

27. O'Donnell VB, Thomas D, Stanton R, et al. Potential role of oral rinses targeting the viral lipid envelope in SARS-CoV-2 infection. Function. 2020;1: zqaa002.

28. Mady LJ, Kubik MW, Baddour K, Snyderman CH, Rowan NR. Consideration of povidone-iodine as a public health intervention for COVID-19: Utilization as "Personal Protective Equipment" for frontline providers exposed in high-risk head and neck and skull base oncology care. Oral Oncol. 2020;105: 104724.

29. Kirk-Bayley J, Challacombe S, Sunkaraneni S, Combes J. The use of povidone iodine nasal spray and mouthwash during the current COVID-19 pandemic may reduce cross infection and protect healthcare workers. 2020. https://doi.org/10.2139/ ssrn.3563092. 